\title{
Mycorrhiza
}

\section{Mycorrhizal fungal growth responds to soil characteristics, but not plant host identity, during a primary lacustrine dune succession \\ --Manuscript Draft--}

\begin{tabular}{|c|c|}
\hline Manuscript Number: & MCOR-D-13-00074R1 \\
\hline Full Title: & $\begin{array}{l}\text { Mycorrhizal fungal growth responds to soil characteristics, but not plant host identity, } \\
\text { during a primary lacustrine dune succession }\end{array}$ \\
\hline Article Type: & Original Paper \\
\hline Keywords: & $\begin{array}{l}\text { arbuscular mycorrhizas; primary succession; soil development; plant-microbe } \\
\text { symbiosis; sand dune }\end{array}$ \\
\hline Corresponding Author: & $\begin{array}{l}\text { Benjamin Sikes, PhD } \\
\text { Kansas Biological Survey and } \\
\text { Lawrence, Kansas UNITED STATES }\end{array}$ \\
\hline \multicolumn{2}{|l|}{$\begin{array}{l}\text { Corresponding Author Secondary } \\
\text { Information: }\end{array}$} \\
\hline Corresponding Author's Institution: & Kansas Biological Survey and \\
\hline \multicolumn{2}{|l|}{$\begin{array}{l}\text { Corresponding Author's Secondary } \\
\text { Institution: }\end{array}$} \\
\hline First Author: & Benjamin Sikes, PhD \\
\hline \multicolumn{2}{|l|}{ First Author Secondary Information: } \\
\hline \multirow[t]{3}{*}{ Order of Authors: } & Benjamin Sikes, PhD \\
\hline & Hafiz Maherali, PhD \\
\hline & John Klironomos, PhD \\
\hline \multicolumn{2}{|c|}{ Order of Authors Secondary Information: } \\
\hline Abstract: & $\begin{array}{l}\text { Soil factors and plant host identity can both affect the growth and functioning of } \\
\text { mycorrhizal fungi. Both components change during primary succession, but it is } \\
\text { unknown if their relative importance to mycorrhizas also changes. This research tested } \\
\text { how soil type and plant host differences among primary successional stages determine } \\
\text { the growth and plant effects of arbuscular mycorrhizal (AM) fungal communities. } \\
\text { Mycorrhizal fungal community, plant identity and soil conditions were manipulated } \\
\text { among three stages of a lacustrine sand dune successional series in a fully factorial } \\
\text { greenhouse experiment. Late succession AM fungi produced more arbuscules and soil } \\
\text { hyphae when grown in late succession soils, although the community was from the } \\
\text { same narrow phylogenetic group as those in intermediate succession. AM fungal } \\
\text { growth did not differ between host species and plant growth was similarly unaffected by } \\
\text { different AM fungal communities. These results indicate that though ecological filtering } \\
\text { and/or adaptation of AM fungi occurs during this primary dune succession, it more } \\
\text { strongly reflects matching between fungi and soils, rather than interactions between } \\
\text { fungi and plant hosts. Thus, AM fungal performance during this succession may not } \\
\text { depend directly on the sequence of plant community succession. }\end{array}$ \\
\hline
\end{tabular}


1 Mycorrhizal fungal growth responds to soil characteristics, but not plant host identity, during a

2

$4 \quad{ }^{1}$ Department of Integrative Biology, University of Guelph, ON, Canada N1G 2W1

$5 \quad{ }^{2}$ Department of Biology, The University of British Columbia - Okanagan, Kelowna, BC, Canada V1V

$6 \quad 1 \mathrm{~V} 7$

$7 \uparrow$ current address: Department of Ecology and Evolutionary Biology and Kansas Biological Survey,

8 University of Kansas, Lawrence, KS 66047, USA

9 corresponding author: Benjamin A. Sikes

10 e-mail: ben.sikes@ku.edu

11 telephone: +785-864-1920

12 fax: +785-864-1534

14 


\section{$23 \underline{\text { Abstract }}$}

24 Soil factors and plant host identity can both affect the growth and functioning of mycorrhizal fungi. Both

25 components change during primary succession, but it is unknown if their relative importance to

26 mycorrhizas also changes. This research tested how soil type and plant host differences among primary

27 successional stages determine the growth and plant effects of arbuscular mycorrhizal (AM) fungal

28 communities. Mycorrhizal fungal community, plant identity and soil conditions were manipulated among

29 three stages of a lacustrine sand dune successional series in a fully factorial greenhouse experiment. Late

30 succession AM fungi produced more arbuscules and soil hyphae when grown in late succession soils,

31 although the community was from the same narrow phylogenetic group as those in intermediate

32 succession. AM fungal growth did not differ between host species and plant growth was similarly

33 unaffected by different AM fungal communities. These results indicate that though ecological filtering

34 and/or adaptation of AM fungi occurs during this primary dune succession, it more strongly reflects

35 matching between fungi and soils, rather than interactions between fungi and plant hosts. Thus, AM

36 fungal performance during this succession may not depend directly on the sequence of plant community

37 succession.

38

39 Keywords: arbuscular mycorrhizas; primary succession; soil development; plant-microbe symbiosis; sand 40 dune

41

42

43

44

45

46 


\section{$50 \quad \underline{\text { Introduction }}$}

Soil biota are critical intermediaries in the process of terrestrial succession. For example,

52 microbes in the detrital food web decompose plant material, thus releasing nutrients for themselves and

53 plants (Harte and Kinzig 1993; Wardle et al. 2004). Changes in plant communities alter the quantity and

54 composition of resource substrates within soils (Zak et al. 2003; Waldrop et al. 2006) which in turn alter

55 soil communities by filtering for microbes with specific traits (Waldrop et al. 2004). However, these

56 indirect feedbacks act more slowly than direct feedbacks from soil organisms that parasitize or benefit

57 plant hosts (De Deyn et al. 2003; Kardol et al. 2006). Soil mutualists are thought to be an important

58 source of direct biotic feedback during succession because they help the majority of plants obtain soil resources (Reynolds et al. 2003; Kardol et al. 2006), but little is known about the relative importance of elements that determine mutualist growth, function and potential for feedback during succession.

Arbuscular mycorrhizal (AM) fungi are likely candidates for direct feedbacks because they are the most widespread soil mutualists in nature (Smith and Read 2008) and differences in AM fungal growth traits may alter mycorrhizal function and plant benefits (Powell et al. 2009). AM fungi can

64 facilitate nutrient uptake, increase resistance to water stress, and enhance pathogen protection in exchange 65 for plant photosynthate (Smith and Read 2008; Brundrett 2009). AM fungal traits such as the extent of 66 colonization within roots, in the surrounding soil and the formation of arbuscules for nutrient transfer vary 67 among fungal species with potential functional consequences (Hart and Reader 2002; Powell et al. 2009).

68 For instance, fungal soil hyphae are more effective than plant roots at nutrient uptake from soil because 69 their smaller diameter results in a much larger surface area to volume ratio (Raven and Edwards 2001).

70 As a result, AM fungal species which produce abundant hyphae in soil facilitate enhanced plant nutrient 71 acquisition (Maherali and Klironomos 2007; Powell et al. 2009).

AM fungal growth and the magnitude of the effect that fungi have on their plant hosts can depend 73 on the identity of both the fungus and host, as well as the soil conditions in which the association occurs 74 (Hoeksema et al. 2010; Johnson 2010). AM fungi in the family Gigasporaceae usually concentrate hyphae 
75 in soil while those in the Glomeraceae produce most hyphae within roots (Hart and Reader 2002). Growth

76 and function of AM fungi also differs among plant host species based on traits such as root morphology

77 (Fitter et al. 2004; Sikes et al. 2009). AM fungal growth and function can also be soil specific. Fungi

78 isolated from soils limited in a specific nutrient, such as phosphorus or nitrogen, produce significantly

79 more soil hyphae and arbuscules as well as transfer more limiting nutrients to plant hosts (Johnson et al.

80 2010) when forming symbioses in these 'home' soils. All three factors: the composition of AM fungal

81 species, plant host identity and soil conditions change over time, therefore succession provides a unique

82 opportunity to test the relative importance of each factor to the growth and functioning of mycorrhizal

83 fungi and their potential to alter plant succession through differential growth benefits to individual plants.

AM fungal species composition, plant host identity and soil conditions were manipulated among

three stages of a primary, lacustrine sand dune successional series in a fully factorial greenhouse

experiment to determine their relative importance to mycorrhizal fungal growth and plant growth.

87 Previous work from this site demonstrated that AM fungal communities in early succession contain sequences from nearly every AM family in the Glomeromycota. Communities from intermediate and late succession contained sequences only from the genus Rhizophagus (Schüßler and Walker 2010) and were dominated by the same single sequence (Sikes et al. 2012). In that study, late successional fungi

91 consistently produced greater numbers of arbuscules and soil hyphae when grown in a common soil

92 combined from all three stages, but no fungal community altered the growth of eight different plant 93 species from across succession (Sikes et al. 2012). Here, it was tested if differences in soil type among

94 successional stages interact with fungal community and host identity to influence fungal traits and benefit 95 to plants. AM fungal communities from each of three stages of succession were grown in each of three 96 successional soil types on one of two plant hosts. Soil types transition from sandy and nutrient poor early

97 successional soils to later successional soils with more organic matter and soil nutrients (Lichter 1998).

98 The two host plants differ in their life history and abundance across succession. Calamovilfa longifolia

99 (Hook.) is a rhizomatous grass that dominates in the open dunes from early to intermediate successional 100 stages whereas Deschampsia flexuosa (L.) is a major understory bunchgrass within the forest that 
101 dominates from intermediate to late succession (Lichter 1998). We hypothesized that AM fungal growth

102 and benefit to hosts would be determined by interactions among all three elements, but soil type would

103 have the strongest effect based on its importance in filtering AM fungal communities (Ji et al. 2012;

104 Schechter and Bruns 2013; Doubková et al. 2013).

105

106 Methods

107 Field Collection and Preparation

108 Each successional component including soils, seeds and fungi was collected and isolated from the

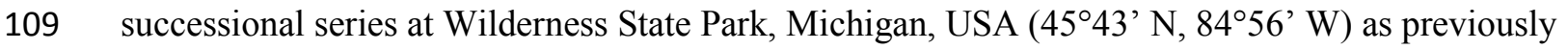
110 described in Sikes et al (2012). The two experiments were setup in parallel and each component was 111 identical. Soils were collected during June 2007 from three pairs of dunes that represent distinctly 112 different stages in both plant community composition and edaphic conditions including soil $\mathrm{pH}$ and soil 113 nutrients (Lichter 1998). Our youngest dunes were 10 and 35 years old respectively, intermediate-aged 114 dunes formed 235-295 years ago, and late successional dunes formed 450 and 845 years ago (Lichter 115 1997). We also collected seeds of $C$. longifolia and D. flexuosa from multiple individuals across the 116 successional series throughout the summer of 2007.

117 AM fungal inoculum from each successional stage was isolated using repeated sucrose118 centrifugation on pooled soil cores from dunes of similar ages (Sikes et al. 2012). Pooled soils were 119 combined from 10 random points along paired dunes. Spores and hyphae were cleaned and hydrated in $120100 \mathrm{ml}$ of autoclaved, de-ionized water (final concentration $18 \mathrm{~g} \mathrm{soil} / \mathrm{ml}$ inoculum). To control for 121 differences in microbial contaminants introduced with each AM fungal community, we also collected a 122 microbial filtrate by passing the initial spore collections through a $25-\mu \mathrm{m}$ sieve. Microbial filtrates from 123 all dunes were combined to represent a common microbial wash added as a control (Koide and Li 1989).

124 Inoculum from each AM fungal community and microbial wash was maintained at $4{ }^{\circ} \mathrm{C}$ for two weeks 125 prior to plant inoculation. 
Soils were sterilized by gamma-irradiation to $32 \mathrm{kGy}$ (McNamara et al. 2003). Forty sterilized

127

128

129

130

soil cores from paired successional stages (twenty from each) were combined to form each soil type:

'Early', 'Intermediate', or 'Late'. This soil was sieved through a sterilized 6-cm sieve to remove larger organic material that could bias individual pots. In addition, we sterilized standard 'play' sand (Hillview;

Ontario, Canada) by autoclaving for one hour. Soils were used to fill mini-tree pots $(6.35 \mathrm{~cm} \mathrm{w} \mathrm{X}$ 25.4cmh, 857ml vol.; Stuewe and Sons; Oregon, USA) for each experimental unit. Each replicate pot consisted of 300ml of 'play' sand on bottom and $600 \mathrm{ml}$ of gamma-irradiated field soil on top.

\section{Soil Nutrient Analysis}

Differences in soil chemistry and nutrients were assessed for three replicate sub-samples of each initial soil type. Each sample was analyzed for soil pH (Hendershot et al. 1993), phosphorus (sodium bicarbonate extraction- (Reid 2006), calcium and magnesium (Ammonium Acetate extraction- (Simard 1993), Total Soil Carbon (Combustion Method- (LECO Corporation 2011), and soil ammonium and nitrate ( $\mathrm{KCl}$ extraction). All analyses except soil ammonium and nitrate were carried out at University of Guelph, Lab Services. Soil ammonium and nitrate were extracted with $\mathrm{KCl}$ and analyzed using spectrophotometry (Maynard and Kalra 1993).

\section{Experimental Setup and Growth}

Seeds from each plant species were surface sterilized, stratified and germinated as in Sikes et al (2012). Seedlings were transplanted within three days of germination. Plants were allowed to grow for two weeks and any seedlings that died following transplantation were replaced. After two weeks, each plant species was inoculated with one of the following AM fungal treatments: 1) sterile water control, 2) microbial wash only, 3) microbial wash + AM fungi from early succession dunes, 4) microbial wash + AM fungi from intermediate age dunes, or 5) microbial wash + AM fungi from late succession dunes. One $\mathrm{ml}$ of fungal inoculum was added directly to the root area using a sterile pipette inserted slightly below the soil surface. One $\mathrm{ml}$ of microbial wash was subsequently added in the same way. Each treatment combination ( 5 AM fungal additions $X 3$ soils $X 2$ plants $=30$ in total) was replicated 10 times for a total of 300 experimental units. Pots were arranged in a randomized complete block design. Drip 
152 irrigation was used to provide $5 \mathrm{ml}$ of water to the pots three times a day and plants were not fertilized (in 153 contrast to Sikes 2012).

154 Plants were grown for four months at which time most individuals were still in vegetative growth 155 with a few larger individuals of both species flowering (less than $10 \%$ of all individuals). Plants were 156 harvested and aboveground plant biomass was weighed, dried at $55^{\circ} \mathrm{C}$ for 3 days and then re-weighed. 157 Plant roots were gently shaken free of soil and washed on a 1-mm sieve for up to 15 min to remove soil 158 particles. Roots were then briefly air dried, weighed, then sub-sampled to stain for arbuscular mycorrhizal 159 structures. The mass of roots sub-sampled for staining varied with the total root biomass available from 160 harvested plants. The average amount taken was $\sim 320 \mathrm{mg}$ of wet root material up to a maximum of $161700 \mathrm{mg}$. Plants that were either dead or had very low root biomass $(<100 \mathrm{mg})$ were not sampled so as to 162 reduce error propagation in biomass measurements. The same quantity of stained roots was used for all 163 fungal quantification (see below). The remaining root biomass was dried as above, then reweighed and 164 final root dry weight estimated by simple proportion (total root wet / total root dry = post-sample root 165 wet/ post-sample root dry). Soils from each replicate were homogenized and 100mg was taken for 166 quantification of extra-radical soil fungal hyphae. Differential staining and microscopy was used to examine differences in AM fungal growth 168 characteristics. AM fungal structures and colonization were quantified using the magnified intersect 169 method (McGonigle et al. 1990) after roots were stained with Chlorazol Black E (Brundrett et al. 1994). 170 AM fungal hyphae were distinguished from other hyphae based on the presence of coenocytic hyphae.

171 Eighteen (2-cm long) root fragments were randomly selected from each subsample and mounted onto two 172 glass slides. For each experimental unit, the presence of arbuscules (the site of exchange between plant 173 and fungus), vesicles (storage structures) and intra-radical hyphae were assessed at 150 intersections. Soil 174 hyphal length was determined by dissolving soil aggregates with sodium hexametaphosphate and then 175 staining and visualizing as above. Hyphal intersections were then converted to hyphal length (Hart and 176 Reader 2002).

\section{Statistical Analysis}


Initial soil characteristics were analyzed using analysis of variance (ANOVA) for each edaphic

179 variable (soil $\mathrm{pH}$ and individual soil nutrients) with soil successional stage (early, intermediate, or late) as

180 the independent variable. It was tested if fungal growth traits, both within and outside plant roots were

181 affected by AM fungal successional stage, soil type, plant identity or their interactions. ANOVAs were

182 run with either number of arbuscules, vesicles, intra-radical hyphae, or soil hyphae as dependent variables

183 and AM fungal successional stage, soil type and plant host species as independent variables and with

184 block as a random factor. 'Control' and 'wash' treatments were excluded from analyses with arbuscules

185 and vesicles because these structures were completely absent from those treatments. Replicates where no

186 roots were taken due to lack of material were also excluded.

The effects of the successional origin of AM fungi, soil type or plant host on total plant biomass,

root biomass, shoot biomass, and the ratio of root biomass to total biomass were determined using multifactor ANOVA models as above.

For all analyses, Tukey post-hoc tests were used on significant factors to analyze specific pairwise comparisons. All analyses were conducted in R (R Development Core Team 2011) and graphics were created in SigmaPlot 11.0 (Systat Software; San Jose, CA).

$194 \underline{\text { Results }}$

\section{Initial Differences among Soil Types}

Successional soil types differed in soil $\mathrm{pH}$ and all measured soil nutrients (Figure 1, $\mathrm{pH}: \mathrm{F}_{2,6}=$ 5558, $\mathrm{p}<0.0001 ; \mathrm{P}: \mathrm{F}_{2,6}=337.28, \mathrm{p}<0.0001 ; \mathrm{Mg}: \mathrm{F}_{2,6}=76.121, \mathrm{p}<0.0001 ; \mathrm{K}: \mathrm{F}_{2,6}=670.88, \mathrm{p}<0.0001, \mathrm{C}$ : $\mathrm{F}_{2,6}=221.09, \mathrm{p}<0.0001 ; \mathrm{NO}_{3}: \mathrm{F}_{2,6}=1850.4, \mathrm{p}<0.0001 ; \mathrm{NH}_{4}: \mathrm{F}_{2,6}=71.85, \mathrm{p}<0.0001$, Supp. Material). Early

199 successional soils were the most basic ( $\mathrm{p}<0.0001$ for all pairwise comparisons) and contained more nitrate 200 than other soils $(\mathrm{p}<0.0001)$. Intermediate successional soils had the most total magnesium $(\mathrm{p}<0.0001)$ but 201 values for all other edaphic factors fell in-between early and late successional soils. Late successional 202 soils were the most acidic and had the most total phosphorus, carbon, potassium, and ammonium $203(\mathrm{p}<0.0001$, Figure 1). 


\section{Differences in Mycorrhizal Traits}

AM fungal traits were influenced by an interaction between AM fungal successional stage and soil type, but not plant species. This interaction was driven by late successional AM fungi, which produced more arbuscules than either early or intermediate AM fungi when in late successional soil, but significantly less arbuscules than other fungi when in early successional soil $\left(\mathrm{F}_{4,127}=29.20, \mathrm{p}<0.0001\right.$, Figure 2A, ANOVA tables in Supp. Material). Late successional AM fungi also produced significantly more soil hyphae than other AM fungi when placed in late successional soil $\left(\mathrm{F}_{8,253}=4.41, \mathrm{p}<0.0001\right.$, Figure 2B). There was a statistically significant difference in intra-radical hyphae among sources of fungal inocula $\left(\mathrm{F}_{4,221}=2.81, \mathrm{p}<0.05\right)$ but there were no significant pairwise differences $(\mathrm{p}>0.05$ for all pairwise comparisons). Hyphae in 'control' and 'wash' treatments were likely a product of background colonization by non-AM fungi. The density of vesicles did not differ among any factors.

\section{Plant Responses to AM fungi and soils}

The successional stage of AM fungi did not influence the biomass of plant hosts. Regardless of the particular measure of biomass (total, shoot, or root), plant growth did not differ among AM fungal inocula (total biomass: $\mathrm{F}_{4,253}=1.91, \mathrm{p}=0.109$, Figure 3, Supp. Material). There were also no significant interactions among AM fungal successional stage, soil type and plant species. Both plant species did have higher growth in intermediate and late successional soils than in early successional soil (total biomass: $\left.\mathrm{F}_{2,253}=1096.19, \mathrm{p}<0.0001\right)$. D. flexuosa biomass increased by $2139 \%$ on average from early to intermediate successional soils, whereas C. longifolia biomass increased by $985 \%$ on average. Both plant species allocated more biomass to roots in early successional soils than those in intermediate and late successional soils $\left(\mathrm{F}_{2,253}=75.73\right.$, $\mathrm{p}<0.0001$, Supp. Material), with $D$. flexuosa shifting more biomass to shoots than $C$. longifolia in intermediate and late succession soils (soil X plant $\mathrm{F}_{2,253}=7.62, \mathrm{p}<0.001$; Figure 4).

\section{$\underline{\text { Discussion }}$}


These results indicate that AM fungal growth within this dune succession depends more on the

successional stage of the fungal community and the specific soil environment than the host plant (Schechter and Bruns 2013). Late successional AM fungi drove this pattern producing the most arbuscules and soil hyphae when forming symbioses in their 'home' soil, and producing the fewest arbuscules in early successional soil. Early and intermediate successional AM fungi did not differ in growth among soil types. The two plant hosts had distinct growth forms, and host growth responded to soil type, but host differences in growth and biomass allocation did not influence the growth of AM fungi from any successional stage. The rapid soil development in this dune succession (Lichter 1998) resulted in substantial differences in edaphic properties among the successional stages represented in our experiment, and these differences may overwhelm any smaller host -derived differences to AM fungal growth. These results indicate that these abiotic changes were more important in determining AM fungal growth than biotic interactions that could have differed between these specific hosts species (Bever 2002; Kiers et al. 2011).

Differences in the formation of arbuscules by late succession AM fungi may reflect a fitness trade-off (Kawecki and Ebert 2004), as a result of late succession AM fungal adaptation to specific soil characteristics. The relatively uniform traits and performance of early and intermediate successional AM fungi across the soil environments suggests that adaptation did not occur in fungi from these environments. However, because we evaluated fungal traits and performance on entire communities of AM fungi, we cannot unambiguously attribute the patterns we observed to adaptation as they may also be a product of differences in phenotypes or communities. Future tests of AM adaptation as a mechanism explaining differences in fungal traits and performance in contrasting soil environments should be done using reciprocal transplants with individual species (e.g., Sherrard and Maherali 2012).

Ecological filtering of AM fungal communities and phenotypic responses of fungi to physical and chemical differences in the soil types could also be mechanisms for differences in AM fungal growth. Species in the diverse early successional AM fungal community are absent from intermediate and late succession, indicating that AM community filtering occurs during succession (Sikes et al. 2012). 
Intermediate and late succession AM fungi consisted of sequences solely from Rhizophagus, including one OTU that accounted for $70 \%$ of all sequences detected in both stages (Sikes et al. 2012). AM fungal diversity was not assessed at the end of the experiment to determine if community changes during the experiment could have resulted in fungal trait differences among soil types. Community divergence between intermediate and late succession AM fungi could have produced distinct growth responses, but early and intermediate succession AM fungal communities could not have converged because they did not overlap in species. The differences in trait responses to soil type between nearly identical starting AM fungal communities may further indicate the importance of examining variation below the species level for understanding mycorrhizal responses to the environment (Koch et al. 2006). In our study, we could not determine whether specific fungal genotypes, species or genera responded to differences in soil type. Given this uncertainty, future work should determine the degree to which variation at each of these levels affects mycorrhizal traits and performance.

Differences in fungal growth did not predict their effects on plant growth, possibly as a result of strong differences in soil nutrient limitation. AM soil hyphae facilitate soil resource acquisition and arbuscules facilitate the transfer of these nutrients to plant roots (Smith and Read 2008; Powell et al. 2009). Yet the soil-specific variation in arbuscules and hyphal growth of late successional AM fungi was not associated with any differences in plant biomass. The lack of an association between plant growth and increased soil hyphae and arbuscles may have been caused by variation in soil nutrient levels across soil types. Phosphorus was higher in the late successional soils compared to previous field observations (Lichter 1998), despite careful collection and storage of soils as well as soil sterilization that should minimize nutrient flushes (McNamara et al. 2003). Bicarbonate extraction also likely underestimated phosphorus in the acidic late successional soils (Olsen et al. 1954). Increased phosphorus may have negated any plant growth benefit from the increased hyphae and arbuscules of late succession AM fungi (Collins and Foster 2009). Mycorrhizal effects on hosts may have also been reduced because plants in the greenhouse were limited by soil resources that AM fungi were unable to provide in sufficient quantity. For example, $\mathrm{N}: \mathrm{P}$ ratios were low in intermediate $(\mathrm{N}: \mathrm{P}=5.1)$ and late successional $(\mathrm{N}: \mathrm{P}=4.0)$ soils 
281

282

283

284

285

286

287

288

289

290

291

292

293

294

295

296

297

298

299

300

301

302

303

304

305

306

(Johnson 2010), indicating that plant growth may have been limited by $\mathrm{N}$ and not P. If no AM fungi could provide $\mathrm{N}$ to plants, then plant growth would have been unaffected by fungal presence. Nevertheless, the lack of fungal growth effects on plants suggests that mycorrhizal fungi can respond directly to soils independently of their influence on plant host growth.

Soil pathogens may also be a missing component necessary to understand the lack of mutualist benefits among successional stages. The "wash" treatment has previously been used as a saprophyte/pathogen treatment to quantify negative interactions (Klironomos 2002). Only C. longifolia in late succession soils showed reduced growth with this treatment compared to control plants. In this study, the "wash" microbial fractions from each successional stage were combined and this pooling could have eliminated stage specific interactions between AM fungi, pathogens/saprobes and hosts. Given the specificity of these interactions (Borowicz 2001; Sikes et al. 2009), it is likely that only certain combinations within a specific soil may have resulted in mycorrhizal benefits. The relative importance of negative and positive soil biotic feedbacks may differ among dune successional stages as it does in secondary succession (Kardol et al. 2006). Kardol et al. (2006) found that negative soil feedbacks were stronger in early succession while positive feedbacks, attributed to mycorrhizal fungi, were stronger in late succession. A combined "wash" inoculum may have reduced the dominance of stage-specific pathogens and thereby eliminated any potential mycorrhizal benefits from pathogen protection.

Our results indicate that soil context is an essential determinant of the growth of a widespread soil mutualist across a successional sequence. The lack of effects by either host suggests obligate mutualists can respond to abiotic environments with little regard for (or effect on) their host. If this type of host independent response to soil environment is common, then there are implications not only for predicting how ecological conditions affect the symbiosis (Johnson 2010; Doubková et al. 2013), but also for understanding how and why it remains stable over evolutionary time (Thrall et al. 2007). For example, if fungal adaptation to soil environments can occur while having neutral effects on hosts, natural selection on AM fungi by the physical environment may be stronger than natural selection imposed by fungal hosts. Our finding that AM fungal traits and performance were decoupled from effects on plant hosts 
307 suggests that soil nutrient conditions can influence AM fungi in ways that are not predictable from plant

308 resource limitation alone (Johnson 2010). Therefore, explaining how soil mutualists affect plant

309 succession requires the explicit incorporation of changes in soil development as a mechanism independent

310 from plant host identity and host resource requirements.

311

312 Acknowledgements:

313 The authors thank Kevin Courtney, Michelle Doucette, Lindsay Wilson and Michael Mucci for help with

314 maintaining the experiment and data collection. BAS was partially supported by an Arthur Richmond

315 Scholarship and an International Scholarship from the University of Guelph. HM and JNK wish to thank

316 the Natural Sciences and Engineering Research Council of Canada (NSERC) for funding.

317

318

319

320

321

322

323

324

325

326

327

328

329

330

331 


\section{References:}

Bever J (2002) Host-specificity of AM fungal population growth rates can generate feedback on plant growth. Plant and Soil 244:281-290.

Borowicz VA (2001) Do arbuscular mycorrhizal fungi alter plant-pathogen relations? Ecology 82:30573068.

Brundrett M (2009) Mycorrhizal associations and other means of nutrition of vascular plants: understanding the global diversity of host plants by resolving conflicting information and developing reliable means of diagnosis. Plant and Soil 320:37-77. doi: 10.1007/s11104-0089877-9.

Brundrett M, Melville L, Peterson L (1994) Practical methods in mycorrhiza research. Mycologue Publications, Waterloo, Canada.

Collins CD, Foster BL (2009) Community-level consequences of mycorrhizae depend on phosphorus availability. Ecology 90:2567-2576.

De Deyn GB, Raaijmakers CE, Zoomer HR, et al. (2003) Soil invertebrate fauna enhances grassland succession and diversity. Nature 422:711-713.

Doubková P, Kohout P, Sudová R (2013) Soil nutritional status, not inoculum identity, primarily determines the effect of arbuscular mycorrhizal fungi on the growth of Knautia arvensis plants. Mycorrhiza. doi: 10.1007/s00572-013-0494-y.

Fitter AH, Heinemeyer A, Husband R, et al. (2004) Global environmental change and the biology of arbuscular mycorrhizas: gaps and challenges. Canadian Journal of Botany 82:1133-1139. doi: 10.1139/b04-045.

Hart MM, Reader RJ (2002) Taxonomic basis for variation in the colonization strategy of arbuscular mycorrhizal fungi. New Phytologist 153:335-344.

Harte J, Kinzig AP (1993) Mutualism and competition between plants and decomposers: implications for nutrient allocation in ecosystems. The American Naturalist 141:829-846.

Hendershot WH, Lalande H, Duquette M (1993) Soil reaction and exchangeable acidity. In: Carter MR (ed) Soil sampling and methods of analysis. CRC Press, Boca Raton,FL, pp 141-146.

Hoeksema JD, Chaudhary VB, Gehring CA, et al. (2010) A meta-analysis of context-dependency in plant response to inoculation with mycorrhizal fungi. Ecology Letters 13:394-407.

Ji B, Bentivenga SP, Casper BB (2012) Comparisons of AM fungal spore communities with the same hosts but different soil chemistries over local and geographic scales. Oecologia 168:187-197.

Johnson NC (2010) Resource stoichiometry elucidates the structure and function of arbuscular mycorrhizas across scales. New Phytologist 185:631-647. doi: 10.1111/j.14698137.2009.03110.x

Johnson NC, Wilson GWT, Bowker MA, et al. (2010) Resource limitation is a driver of local adaptation in mycorrhizal symbioses. Proceedings of the National Academy of Sciences 107:2093-2098. 
369

370

371

372

373

374

375

376

377

378

379

380

381

382

383

384

385

386

387

388

389

390

391

392

393

394

395

396

397

398

399

400

401

402
Kardol P, Martijn Bezemer T, van der Putten WH (2006) Temporal variation in plant-soil feedback controls succession. Ecology Letters 9:1080-1088.

Kawecki TJ, Ebert D (2004) Conceptual issues in local adaptation. Ecology Letters 7:1225-1241.

Kiers ET, Duhamel M, Beesetty Y, et al. (2011) Reciprocal Rewards Stabilize Cooperation in the Mycorrhizal Symbiosis. Science 333:880-882. doi: 10.1126/science.1208473

Klironomos JN (2002) Feedback with soil biota contributes to plant rarity and invasiveness in communities. Nature 417:67-70.

Koch AM, Croll D, Sanders IR (2006) Genetic variability in a population of arbuscular mycorrhizal fungi causes variation in plant growth. Ecology Letters 9:103-110.

Koide RT, Li M (1989) Appropriate controls for vesicular-arbuscular mycorrhiza research. New Phytologist 111:35-44.

LECO Corporation (2011) LECO SC-444 Instruction Manual, Michigan, USA.

Lichter J (1998) Primary Succession and Forest Development on Coastal Lake Michigan Sand Dunes. Ecological Monographs 68:487-510.

Lichter J (1997) AMS radiocarbon dating of Lake Michigan beach-ridge and dune development. Quaternary Research 48:137-140.

Maherali H, Klironomos JN (2007) Influence of phylogeny on fungal community assembly and ecosystem functioning. Science 316:1746-1748. doi: 10.1126/science.1143082

Maynard DG, Kalra YP (1993) Nitrate and exchangeable ammonium nitrogen. Soil sampling and methods of analysis. CRC Press, Boca Raton,FL, pp 25-38

McGonigle TP, Miller MH, Evans DG, et al. (1990) A new method which gives an objective measure of colonization of roots by vesicular-arbuscular mycorrhizal fungi. New Phytologist 115:495-501.

McNamara NP, Black HIJ, Beresford NA, Parekh NR (2003) Effects of acute gamma irradiation on chemical, physical and biological properties of soils. Applied Soil Ecology 24:117-132.

Olsen SR, Cole CV, Watanabe FS, Dean LA (1954) Estimation of available phosphorus by extraction with sodium bicarbonate (Circular 39). USDA, Washington, DC.

Powell JR, Parrent JL, Hart MM, et al. (2009) Phylogenetic trait conservatism and the evolution of functional trade-offs in arbuscular mycorrhizal fungi. Proceedings of the Royal Society B 276:4237-4235.

R Development Core Team (2011) R: A Language and Environment for Statistical Computing. Vienna, Austria.

Raven JA, Edwards D (2001) Roots: evolutionary origins and biogeochemical significance. J Exp Bot 52:381-401.

Reid K (2006) Soil fertility handbook. Ministry of Agriculture, Food and Rural Affairs, Ontario, Canada. 
419

422

423

424

425

426

427

428

429

430

431

432

433

434

435

436

Reynolds HL, Packer A, Bever JD, Clay K (2003) Grassroots ecology: plant-microbe-soil interactions as drivers of plant community structure and dynamics. Ecology 84:2281-2291.

Schechter SP, Bruns TD (2013) A common garden test of host-symbiont specificity supports a dominant role for soil type in determining AMF assemblage structure in Collinsia sparsiflora. PLoS ONE 8:e55507.

Schüßler A, Walker C (2010) The Glomeromycota: a species list with new families and new genera. The Royal Botanic Garden Kew, Botanische Staatssammlung Munich, and Oregon State University. http://schuessler.userweb.mwn.de/amphylo/Schuessler\&Walker2010_Glomeromycota.pdf Accessed 18 September 2013.

Sherrard ME, Maherali H (2012) Local adaptation across a fertility gradient is influenced by soil biota in the invasive grass, Bromus inermis. Evol Ecol 26:529-544. doi: 10.1007/s10682-011-9518-2.

Sikes BA, Cottenie K, Klironomos JN (2009) Plant and fungal identity determines pathogen protection of plant roots by arbuscular mycorrhizas. Journal of Ecology 97:1274-1280.

Sikes BA, Maherali H, Klironomos JN (2012) Arbuscular mycorrhizal fungal communities change among three stages of primary sand dune succession but do not alter plant growth. Oikos 121:17911800. doi: 10.1111/j.1600-0706.2012.20160.x.

Simard RR (1993) Ammonium acetate-extractable elements. In: Carter MR (ed) Soil sampling and methods of analysis. Lewis Publishers, Boca Raton,FL, pp 39-42.

Smith SE, Read DJ (2008) Mycorrhizal symbiosis. Academic press, San Diego.

Thrall PH, Hochberg ME, Burdon JJ, Bever JD (2007) Coevolution of symbiotic mutualists and parasites in a community context. Trends in Ecology \& Evolution 22:120-126.

Waldrop MP, Zak DR, Blackwood CB, et al. (2006) Resource availability controls fungal diversity across a plant diversity gradient. Ecology Letters 9:1127-1135.

Waldrop MP, Zak DR, Sinsabaugh RL (2004) Microbial community response to nitrogen deposition in northern forest ecosystems. Soil Biol Biochem 36:1443-1451. doi:

10.1016/j.soilbio.2004.04.023.

Wardle DA, Bardgett RD, Klironomos JN, et al. (2004) Ecological linkages between aboveground and belowground biota. Science 304:1629-1633.

Zak DR, Holmes WE, White DC, et al. (2003) Plant diversity, soil microbial communities, and ecosystem function: Are there any links? Ecology 84:2042-2050. doi: 10.1890/02-0433. 
438 Figure 1 Total soil phosphorus (A), carbon (B), potassium (C), magnesium (D), nitrate (E), ammonium $439(\mathrm{~F})$, and soil $\mathrm{pH}(\mathrm{G})$ among soil types. Error bars represent standard error of the mean. Letters indicate 440 significant pairwise differences $(\mathrm{p}<0.05)$ in each factor among soil types. Soil types are pooled from 441 respective successional stage as outlined in Methods: Early-soils from dunes 15-35 years old,

442 Intermediate (Inter.)-soils from dunes 235-295 years old, Late-soils from dunes 450-835 years old 443

444 Figure 2: Arbuscule (\% root length colonized) and soil hyphal length $(\mathrm{cm})$ for individual treatments 445 based on AM fungal inoculum, soil type and plant species. AM fungal additions are as follows 'Control'water only, 'Wash'- microbial wash only, 'Early'- microbial wash + early successional AM fungi, 'Intermediate'- microbial wash + intermediate successional AM fungi, and 'Late'- microbial wash + late successional AM fungi. Legend indicates colors for each fungal inoculum added. Letters below the figure indicate significant pairwise differences $(\mathrm{p}<0.05)$ in combinations of AM fungal additions and soil type.

450 There were no arbuscules in either control or wash treatments therefore they were excluded from the 451 graphs. Soil types and symbols are as in Figure 1. Plant species are C. longifolia- Calamovilfa longifolia 452 (early successional) and D. flexuosa- Deschampsia flexuosa (late succession).

454 Figure 3: The effect of soil type and inoculum addition on total biomass for each plant species. All 455 abbreviations and inocula are as in figure 2. Letters below the figure indicate significant pairwise 456 differences $(\mathrm{p}<0.05)$ between soil types.

458 Figure 4: The ratio of root to total biomass for each plant species grown in each soil type and with each 459 AM fungal inoculum. All abbreviations and symbols are as in figure 2. 


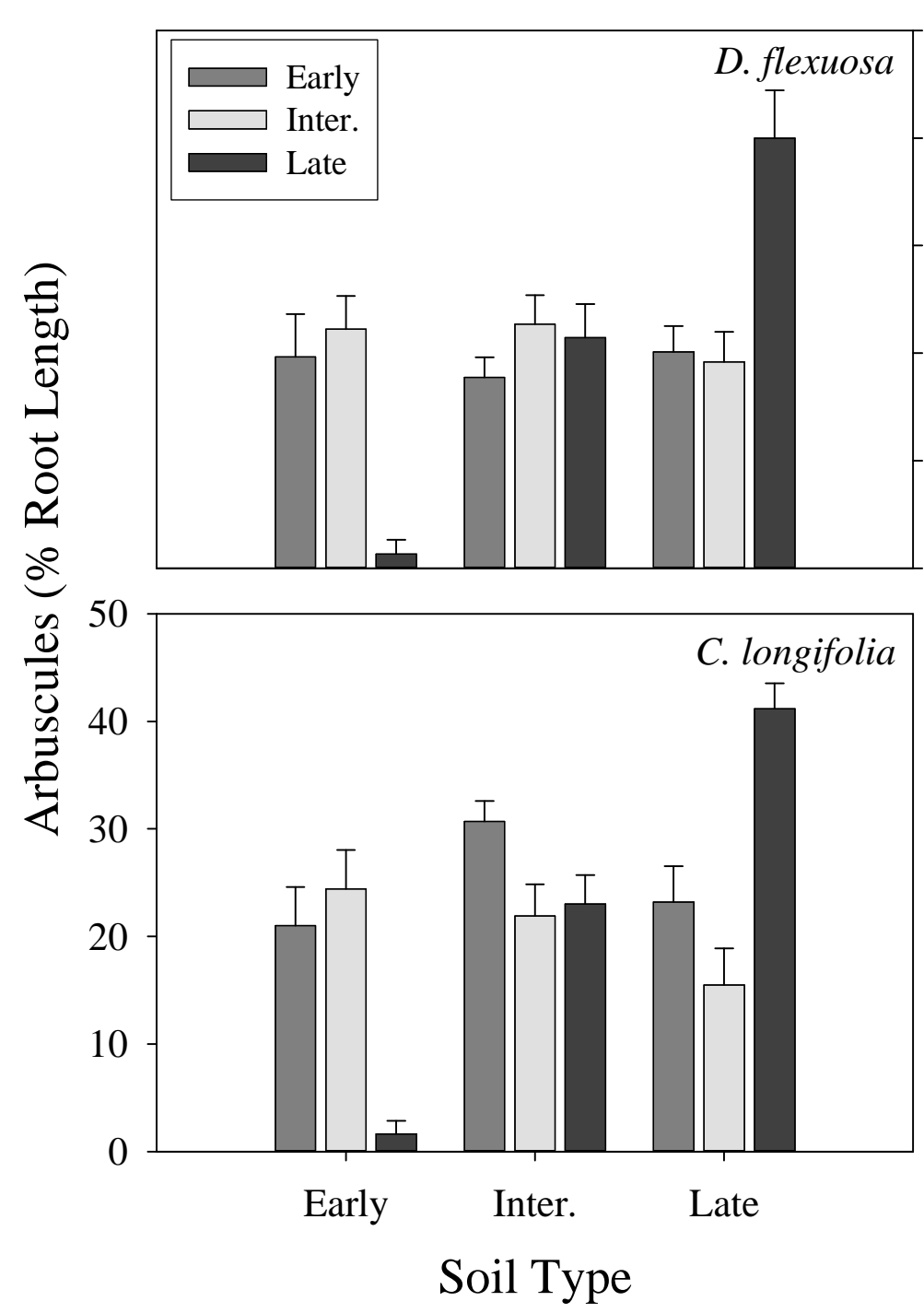

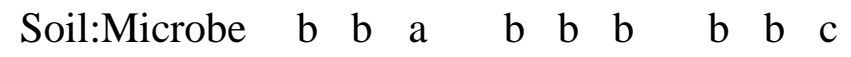
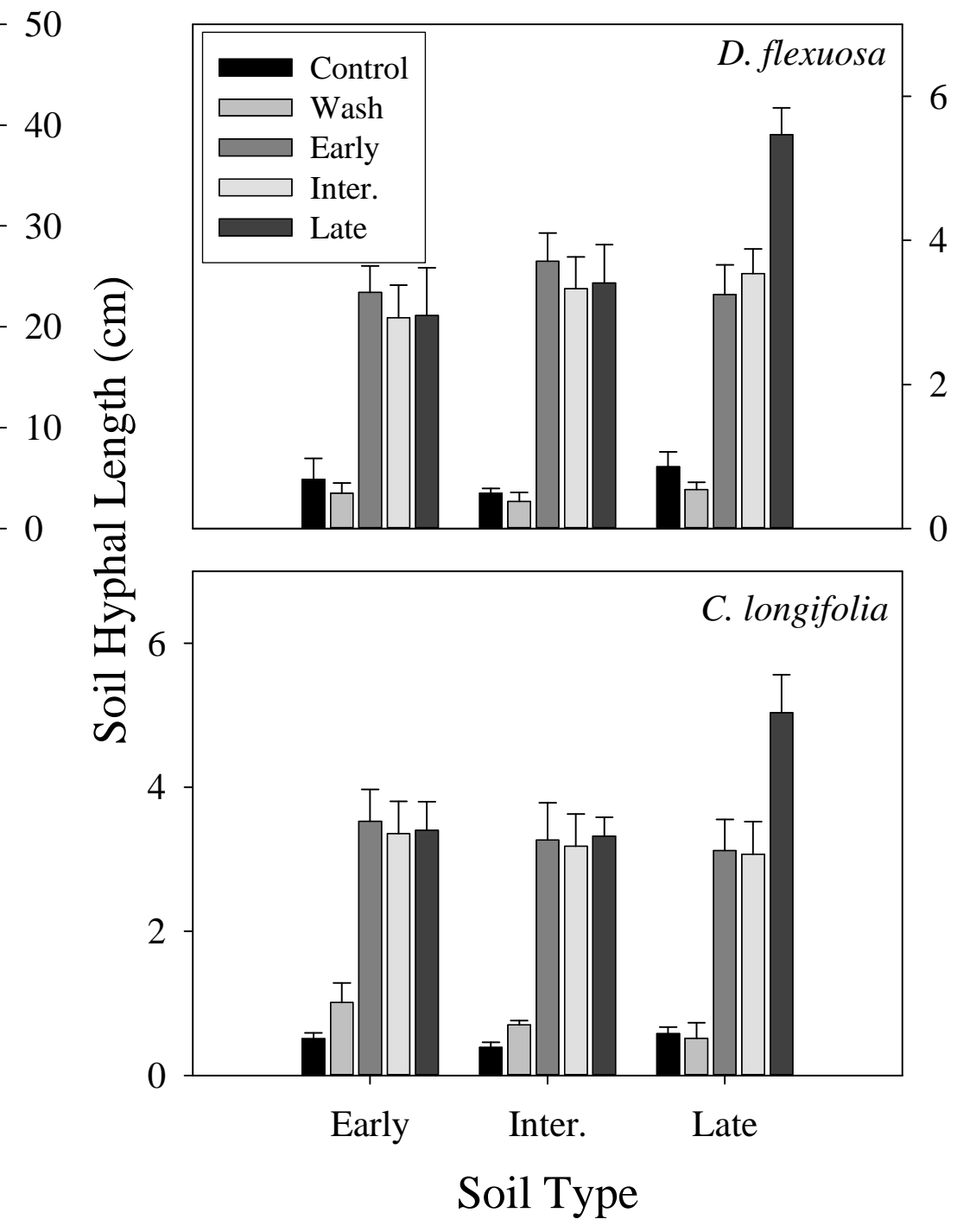

$a \mathrm{abb} \quad \mathrm{a} a \mathrm{bb} \quad \mathrm{a} a \mathrm{bbc}$ 


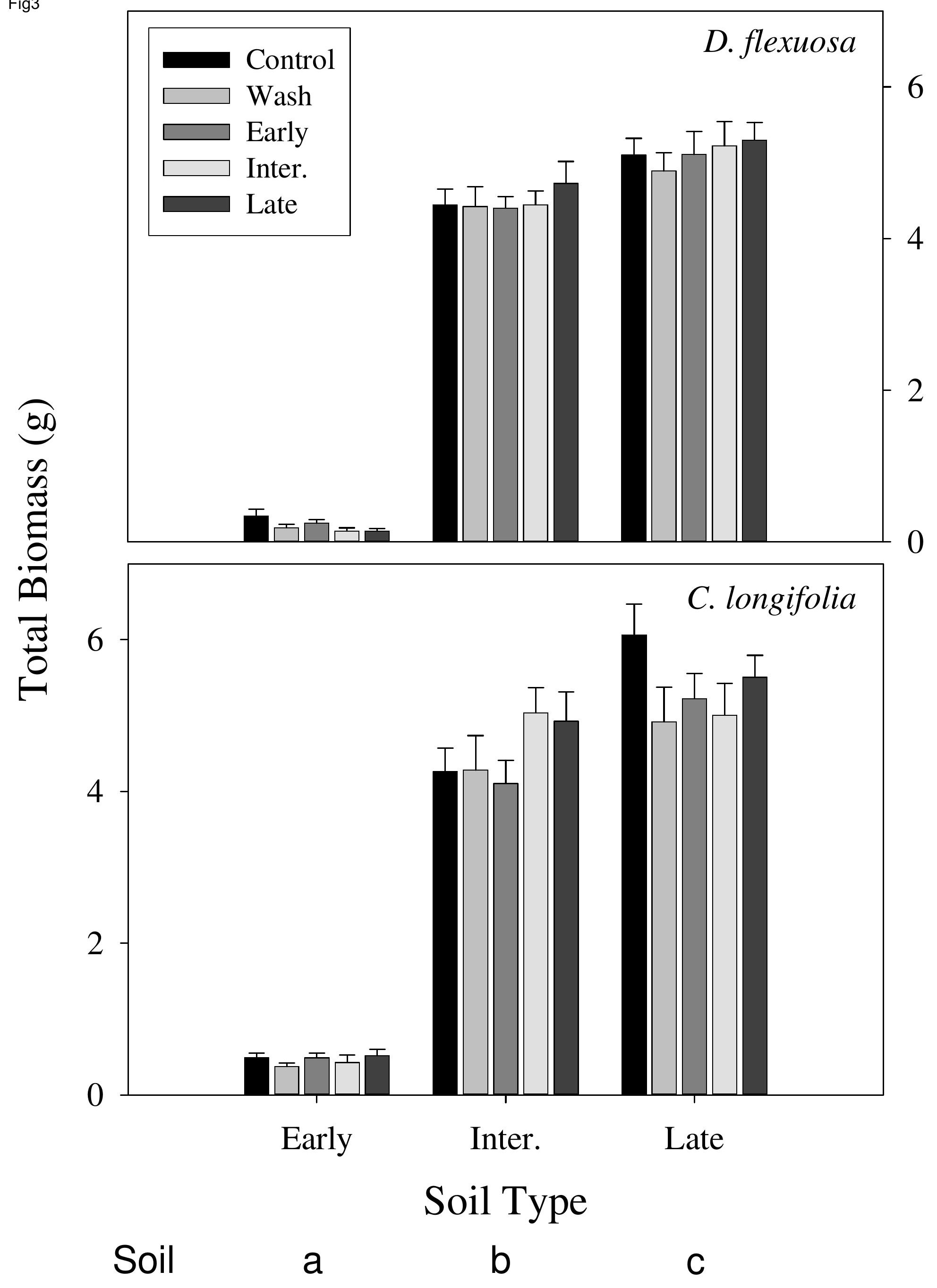

Soil

a

b

C 
Mycorrhiza Supplmentary Materials

\section{Mycorrhizal fungal growth responds to soil characteristics, but not plant host identity, during a primary lacustrine sand dune succession}

Benjamin A. Sikes ${ }^{1+}$, Hafiz Maherali ${ }^{1}$ and John N. Klironomos ${ }^{3}$

${ }^{1}$ Department of Integrative Biology, University of Guelph, ON, Canada

N1G 2W1

${ }^{2}$ Department of Biology, The University of British Columbia -

Okanagan, Kelowna, BC, Canada V1V 1V7

$\dagger$ corresponding author: Benjamin A. Sikes

current address: Department of Ecology and Evolutionary Biology and Kansas Biological Sı

e-mail: ben.sikes@ku.edu

telephone: +785-864-1920

fax: +785-864-1534

Soil Variables Among Successional Stages

\begin{tabular}{|c|c|c|c|}
\hline \multicolumn{1}{|c}{ Variable } & \multicolumn{1}{c}{ dF } & \multicolumn{1}{c|}{ F-value } & P-value \\
\hline $\mathrm{pH}$ & 2,6 & 5558 & $\mathbf{1 . 5 7 E - 1 0}$ \\
\hline $\mathrm{P}$ & 2,6 & 337.28 & $\mathbf{6 . 8 5 E}-07$ \\
\hline $\mathrm{Mg}$ & 2,6 & 76.121 & $\mathbf{5 . 4 5 E}-05$ \\
\hline $\mathrm{K}$ & 2,6 & 670.88 & $\mathbf{8 . 8 2 E}-08$ \\
\hline $\mathrm{C}$ & 2,6 & 221.09 & $\mathbf{2 . 4 0 E}-06$ \\
\hline $\mathrm{NO}_{3}$ & 2,6 & 1968.6 & $\mathbf{3 . 5 2 E}-09$ \\
\hline $\mathrm{NH}_{4}$ & 2,6 & 73.861 & $\mathbf{5 . 9 5 E - 0 5}$ \\
\hline
\end{tabular}

Mycorrhizal Traits Among AMF communities, soil types and plant hosts

Arbuscules

microbe

Df

\begin{tabular}{|c|c|c|c|c|c|}
\hline \multicolumn{2}{|c|}{ Sum Sq } & Mean Sq & F-value & $\operatorname{Pr}(>\mathrm{F})$ & Sign. \\
\hline 2 & 587.7 & 293.83 & 3.5973 & 0.0302 & $2 *$ \\
\hline 2 & 2743.7 & 1371.87 & 16.7954 & $3.33 \mathrm{E}-07$ & $7 * * *$ \\
\hline 1 & 96.6 & 96.61 & 1.1828 & 0.2788 & \\
\hline 9 & 407.3 & 45.26 & 0.5541 & 0.8322 & \\
\hline 4 & 9486.5 & 2371.62 & 29.035 & $<2.20 \mathrm{E}-16$ & $5 * * *$ \\
\hline 2 & 357.5 & 178.73 & 2.1881 & 0.1163 & \\
\hline 2 & 120.5 & 60.23 & 0.7373 & 0.4804 & \\
\hline 4 & 244.1 & 61.03 & 0.7472 & 0.5616 & \\
\hline & 10455.2 & 81.68 & & & \\
\hline
\end{tabular}

$\underline{\text { Vesicles }}$

microbe

Df

Sum Sq Mean Sq F-value $\operatorname{Pr}(>\mathrm{F})$

soil

plant

$2 \quad 137.6$

68.778

2.3418

0.10027

2142.2

71.104

2.421

0.09289 .

block

10.001

$9 \quad 366 \quad 40.664$

1.3845

0.9956

0.20166 


\begin{tabular}{|c|c|c|c|c|c|c|}
\hline microbe:soil & & 4 & 73.5 & 18.369 & 0.6254 & 0.6452 \\
\hline microbe:plant & & 2 & 17.7 & 8.853 & 0.3014 & 0.7403 \\
\hline soil:plant & & 2 & 19.9 & 9.947 & 0.3387 & 0.71335 \\
\hline microbe:soil:plant & & 4 & 148.4 & 37.107 & 1.2634 & 0.28782 \\
\hline Residuals & & 128 & 3759.4 & 29.37 & & \\
\hline \multicolumn{7}{|l|}{ Intraradical Hyphae } \\
\hline & Df & \multicolumn{2}{|c|}{ Sum Sq } & Mean Sq & F-value & $\operatorname{Pr}(>\mathrm{F})$ \\
\hline microbe & & 4 & 1616 & 403.89 & 2.808 & $0.0265 *$ \\
\hline soil & & 2 & 795 & 397.67 & 2.7648 & 0.06517 . \\
\hline plant & & 1 & 112 & 111.56 & 0.7756 & 0.37944 \\
\hline block & & 9 & 1141 & 126.83 & 0.8818 & 0.5423 \\
\hline microbe:soil & & 8 & 1347 & 168.42 & 1.1709 & 0.31778 \\
\hline microbe:plant & & 4 & 471 & 117.71 & 0.8184 & 0.51465 \\
\hline soil:plant & & 2 & 301 & 150.74 & 1.048 & 0.35237 \\
\hline microbe:soil:plant & & 8 & 881 & 110.12 & 0.7656 & 0.63347 \\
\hline Residuals & & 221 & 31787 & 143.83 & & \\
\hline
\end{tabular}

Extraradical Hyphae

\begin{tabular}{|c|c|c|c|c|c|}
\hline & Df & $\mathrm{m} \mathrm{Sq}$ & Mean Sq & F-value & $\operatorname{Pr}(>F)$ \\
\hline microbe & 4 & 621.73 & 155.433 & 124.4454 & $<2.20 \mathrm{E}-16 * * *$ \\
\hline soil & 2 & 9.54 & 4.769 & 3.8186 & $0.02324 *$ \\
\hline plant & 1 & 0.06 & 0.062 & 0.0497 & 0.82383 \\
\hline block & 9 & 6.09 & 0.677 & 0.5419 & 0.84319 \\
\hline microbe:soil & 8 & 44.08 & 5.511 & 4.4119 & $5.16 \mathrm{E}-05 * * *$ \\
\hline microbe:plant & 4 & 1.65 & 0.411 & 0.3294 & 0.85808 \\
\hline soil:plant & 2 & 4.69 & 2.347 & 1.8791 & 0.15485 \\
\hline microbe:soil:plant & 8 & 1.84 & 0.23 & 0.1838 & 0.99298 \\
\hline Residuals & 253 & 316 & 1.249 & & \\
\hline
\end{tabular}

Plant Metrics Among AMF communities, soil types and plant hosts

$\underline{\text { Relative Water Content (RWC) }}$

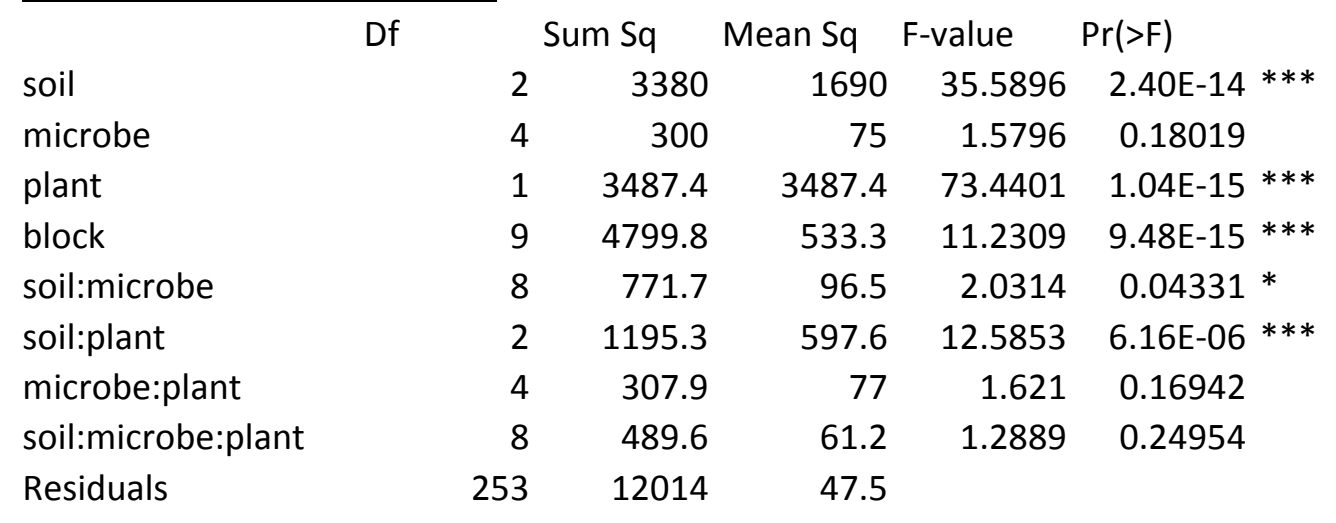

$\underline{\text { Total Biomass }}$ 


$\begin{array}{lrrrrc}\text { soil } & 2 & 1345.04 & 672.52 & 1096.194<2.20 \mathrm{E}-16 * * * \\ \text { microbe } & 4 & 4.69 & 1.17 & 1.9114 & 0.109 \\ \text { plant } & 1 & 2.03 & 2.03 & 3.3136 & 0.06989 \\ \text { block } & 9 & 22.22 & 2.47 & 4.0238 & 7.89 \mathrm{E}-05 * * * \\ \text { soil:microbe } & 8 & 6.27 & 0.78 & 1.2775 & 0.25554 \\ \text { soil:plant } & 2 & 0.56 & 0.28 & 0.4549 & 0.63502 \\ \text { microbe:plant } & 4 & 0.97 & 0.24 & 0.3949 & 0.8122 \\ \text { soil:microbe:plant } & 8 & 5.81 & 0.73 & 1.1838 & 0.30911 \\ \text { Residuals } & 253 & 155.22 & 0.61 & & \end{array}$

\section{$\underline{\text { Root:Total Biomass Ratio }}$}

\begin{tabular}{|c|c|c|c|c|c|c|}
\hline & Df & \multicolumn{2}{|c|}{ Sum Sq } & Mean Sq & F-value & $\operatorname{Pr}(>\mathrm{F})$ \\
\hline soil & & 2 & 1.45264 & 0.72632 & 75.7324 & $<2.20 \mathrm{E}-16 * * *$ \\
\hline microbe & & 4 & 0.07954 & 0.01988 & 2.0733 & 0.084779 \\
\hline plant & & 1 & 1.85073 & 1.85073 & 192.9738 & $<2.20 \mathrm{E}-16 * * *$ \\
\hline block & & 9 & 0.22108 & 0.02456 & 2.5613 & $0.007797 * *$ \\
\hline soil:microbe & & 8 & 0.04413 & 0.00552 & 0.5751 & 0.797976 \\
\hline soil:plant & & 2 & 0.14623 & 0.07312 & 7.6237 & $0.00061 * * *$ \\
\hline microbe:plant & & 4 & 0.01135 & 0.00284 & 0.2959 & 0.880485 \\
\hline soil:microbe:plant & & 8 & 0.05011 & 0.00626 & 0.6532 & 0.732407 \\
\hline Residuals & & 253 & 2.42642 & 0.00959 & & \\
\hline \multicolumn{7}{|l|}{ Leaves } \\
\hline & Df & \multicolumn{2}{|c|}{ Sum Sq } & Mean Sq & F-value & $\operatorname{Pr}(>F)$ \\
\hline soil & & 2 & 333 & 166.5 & 1100.894 & $<2.20 \mathrm{E}-16 * * *$ \\
\hline microbe & & 4 & 1.72 & 0.43 & 2.8382 & $0.024964 *$ \\
\hline plant & & 1 & 894 & 894 & 5911.102 & $<2.20 \mathrm{E}-16^{* * *}$ \\
\hline block & & 9 & 2.37 & 0.26 & 1.7412 & 0.080274 \\
\hline soil:microbe & & 8 & 3.19 & 0.4 & 2.6333 & $0.008709 * *$ \\
\hline soil:plant & & 2 & 69.64 & 34.82 & 230.2329 & $<2.20 \mathrm{E}-16 * * *$ \\
\hline microbe:plant & & 4 & 0.51 & 0.13 & 0.848 & 0.495968 \\
\hline soil:microbe:plant & & 8 & 1.83 & 0.23 & 1.5132 & 0.152896 \\
\hline Residuals & & 250 & 37.81 & 0.15 & & \\
\hline
\end{tabular}


urvey, University of Kansas, Lawrence, KS 66047, USA 


\section{Arbuscles}

Microbe:Soil

Mid:Early-Early:Early

Late:Early-Early:Early

Early:Mid-Early:Early

Mid:Mid-Early:Early

Late:Mid-Early:Early

Early:Late-Early:Early

Mid:Late-Early:Early

Late:Late-Early:Early

Late:Early-Mid:Early

Early:Mid-Mid:Early

Mid:Mid-Mid:Early

Late:Mid-Mid:Early

Early:Late-Mid:Early

Mid:Late-Mid:Early

Late:Late-Mid:Early

Early:Mid-Late:Early

Mid:Mid-Late:Early

Late:Mid-Late:Early

Early:Late-Late:Early

Mid:Late-Late:Early

Late:Late-Late:Early

Mid:Mid-Early:Mid

Late:Mid-Early:Mid

Early:Late-Early:Mid

Mid:Late-Early:Mid

Late:Late-Early:Mid

Late:Mid-Mid:Mid

Early:Late-Mid:Mid

Mid:Late-Mid:Mid

Late:Late-Mid:Mid

Early:Late-Late:Mid

Mid:Late-Late:Mid

Late:Late-Late:Mid

Mid:Late-Early:Late

Late:Late-Early:Late

Late:Late-Mid:Late

\begin{tabular}{|c|c|c|c|}
\hline diff & Iwr & upr & $\mathrm{p}$ adj \\
\hline 4.657449 & -6.908 & 16.2229 & 0.937898 \\
\hline-19.3645 & -30.6101 & -8.11884 & $9.5 \mathrm{E}-06$ \\
\hline 3.662401 & -6.24166 & 13.56646 & 0.961888 \\
\hline 1.69076 & -7.98559 & 11.36711 & 0.999777 \\
\hline 1.731947 & -8.05293 & 11.51682 & 0.999755 \\
\hline 0.999635 & -8.67672 & 10.67599 & 0.999996 \\
\hline-3.28855 & -12.9649 & 6.387806 & 0.977118 \\
\hline 20.19777 & 10.62066 & 29.77487 & $0 * * *$ \\
\hline-24.0219 & -36.3999 & -11.6439 & $4 \mathrm{E}-07 * * *$ \\
\hline-0.99505 & -12.1683 & 10.17824 & 0.999999 \\
\hline-2.96669 & -13.9386 & 8.005263 & 0.994848 \\
\hline-2.9255 & -13.9933 & 8.142276 & 0.995588 \\
\hline-3.65781 & -14.6298 & 7.314137 & 0.979698 \\
\hline-7.94599 & -18.9179 & 3.025957 & 0.358705 \\
\hline 15.54032 & 4.655796 & 26.42484 & 0.000492 \\
\hline 23.02685 & 12.18497 & 33.86873 & $0 * * *$ \\
\hline 21.05521 & 10.42094 & 31.68948 & $2 \mathrm{E}-07 * * *$ \\
\hline 21.0964 & 10.36328 & 31.82951 & $3 \mathrm{E}-07 * * *$ \\
\hline 20.36409 & 9.729814 & 30.99836 & $6 \mathrm{E}-07 * * *$ \\
\hline 16.07591 & 5.441634 & 26.71018 & $0.000168 * * *$ \\
\hline 39.56222 & 29.01817 & 50.10626 & $0 * * *$ \\
\hline-1.97164 & -11.1757 & 7.232405 & 0.999 \\
\hline-1.93045 & -11.2485 & 7.387617 & 0.999216 \\
\hline-2.66277 & -11.8668 & 6.541279 & 0.991876 \\
\hline-6.95095 & -16.155 & 2.2531 & 0.302169 \\
\hline 16.53537 & 7.435718 & 25.63502 & $2.4 \mathrm{E}-06 * * *$ \\
\hline 0.041187 & -9.03448 & 9.116858 & 1 \\
\hline-0.69113 & -9.64969 & 8.267435 & 1 \\
\hline-4.97931 & -13.9379 & 3.979255 & 0.711739 \\
\hline 18.50701 & 9.655739 & 27.35828 & $0 * * *$ \\
\hline-0.73231 & -9.80798 & 8.343359 & 0.999999 \\
\hline-5.02049 & -14.0962 & 4.055179 & 0.717013 \\
\hline 18.46582 & 9.496041 & 27.4356 & $1 \mathrm{E}-07 * * *$ \\
\hline-4.28818 & -13.2467 & 4.670381 & 0.848629 \\
\hline 19.19813 & 10.34687 & 28.0494 & $0 * * *$ \\
\hline 23.48631 & 14.63505 & 32.33758 & $0 * * *$ \\
\hline
\end{tabular}

